numerous and too exact to leave room for doubt. "By this means," writes Captain Spratt, "I was enabled to trace the extent of the Nile's influence both directly off the coast and along it, as well as to ascertain the large quantity of sand-pure silicious sand-it must annually bring to the sea; and to an amount which far exceeded my expectations and experience in respect to other rivers, particularly that of the Danube, which, in comparison, brings a very much less proportion of sand to mud. The Danube sand, also, is of the finest quality. The Nile sand, on the contrary, is much coarser generally, and forms sandbanks off the coast that are composed of quartzose sand nearly as large as mustard seed."

The quantity of solid matter brought down by the Nile when in flood is prodigious, and precisely at this season -that is, for three or four months - the north-west winds blow strongest. Indeed, if the wind did not blow with the violence of a monsoon it would be impossible for sailing-vessels to navigate the river during the time of its rise. The suspended matter is consequently driven to the eastward along the coast, and there accumulating forms dunes or sandhills, which shift their position with every gale, "burying at times the huts of the coastguard men." The hollows between the dunes are cultivated by the Arabs, but the plots must be protected by screens of reeds, against which the sand accumulates by repetition, until in some instances the hill is a hundred feet in height. Captain Spratt here remarks: "The best efforts of a population of several thousand Arabs, who inhabit the villages along this strip of land, fail in permanently fixing these dunes. For as the sea continually reaccumulates the sand upon the beach, onward it moves, in spite of those efforts, and the rate of progress may be imagined when I state that a mosque near Brulos has in about twelve months been nearly buried in one of the dunes" advancing from the westward. "And as the coarse sand of which these hills are composed is not distinguishable in differing from the sands of the desert near the Pyramids, or that on the route to Suez, they must undoubtedly be all the gifts of the Nile."

Besides coarse sand the Nile carries down fragments of brick, pottery, and other heavy substances, which are also drifted along the coast by the combined action of wind and current. When the wind blows its strongest the coastguard men say they cannot walk against it. To test these facts, Captain Spratt one day landed eleven bags of ashes and clinkers, five of the bags containing pure clinkers, the largest of which weighed from four to five pounds. The whole were laid in a heap just above the water's edge, and left to the care of wind and sea. 'Twelve days later, when the party returned, not a vestige of the heap, which had weighed nearly two tons, was to be seen. The shore was examined towards the quarter from which the wind blew, but without result; while in the other direction, that of the prevailing wave movement, clinkers weighing about two ounces were found dispersed to a distance of fully 1,500 yards, one of $3 \frac{1}{2}$ pounds was picked up at 240 yards, and others from 4 to 8 ounces at from 600 to 700 yards. The greater portion had, however, been buried by the movement of the sand. "Thus this evidence," writes Captain Spratt, " of the movement of the beach in only twelve days, in the month of May, during which there was but one strong westerly breeze and several fresh easterly breezes, is a positive evidence of the great easterly movement of the shore and littoral shallows along this coast, but which, during a succession of winter gales, and during the prevailing north-west breezes at the period of high Nile, must cause a continuous progression of an immense quantity of the sands and matter carried out by the turbid river."

We quote another passage bearing on this point. The captain was walking along the coast for the purpose of observation, from the beacon marking the site of Port Said, to the head of the bay of Tineh, when he found a great quantity of broken pottery, broken jars, ancient and modern, and broken bricks scattered on the shore, at the highest and lowest surf margin. "On discovering them in such quantity" he continues, "I was naturally anxious to trace out their origin, thinking they must have come from some adjacent ruin. But I found eventually that they had come wholly from the mouths of the Nile, and that they were the positive débris from the towns situated on the banks of the river, and brought out by the strength of the current at high Nile, but then dispersed along the coast to the eastward by its littoral currents and prevailing ground swell."

It would be easy to multiply facts, if further evidence were wanted, that the Nile is no exception in the great transforming powers of Nature, washing down the dry land into the sea, and forming there beneath and on the margin of the waves new continents and islands. The Mississippi, the Ganges, the Yang-tse-Kiang, and other rivers of the great continents, carry down millions of tons of solid matter every year. The North Sea is gradually being silted up by the rivers of Belgium, Holland, and the British islands. At the mouth of the Ebro, on the northern side of the Mediterranean, the deposits brought down by the river are in course of reclamation by an eminent English engineer. Hence we need not feel surprise that the Nile-one of the greatest of rivers-has during long ages wrought great changes on the southern shores of the same sea. In the face of facts such as are above adduced, a government or a nation might well be justified in believing the project of a harbour and canal on the Bay of Pelusium to be, if not impossible of execution, at least unprofitable. Places which were on the shore when Strabo wrote are now from four to six miles inland, as is shown on the accompanying map, reduced from that published with Captain Spratt's report; and this modifying action is still going on.

Since the Suez canal was first projected engineering science has advanced; and though the sands will accumulate at Port Saïd as from of old, the piers and breakwaters will be periodically lengthened, made to stretch further and further into the sea, while powerful steamdredges will scrape away the sand from the mouth of the harbour. Whether heavy gales will effect any more serious choking of the approaches, or drift tons of blowing sand into the canal itself remains to be seen. But while the world is greeting, and worthily greeting, the great work as a triumph of engineering skill, it may be well, at the same time, to bestow a little thought on the facts and conclusions here brought under notice, which in the pre-scientific age rendered man's contests against the works of the winds and sea perfectly hopeless.

\section{MEETING OF THE AMERICAN ASSOCIATION}

\section{FOR THE ADVANCEMENT OF SCIENCE}

T $\mathrm{N}$ the last number of Silliman's fournal is an account of this year's meeting of the American Association, held at Salem, under the presidency of Mr. J. M. Foster, of Chicago, which seems to have passed off as pleasantly and usefully as did our own at Exeter. Over one hundred and fifty new members were elected. The number of communications entered upon the daily programmes of the Standing Committee was about one hundred and fifty. The range of these papers was considerable, and it was found expedient to have sub-sections on Archæology and Microscopy, to facilitate the disposal of papers which could not be reached in the other sections.

The then recent total eclipse of the sun was naturally a prominent subject of interest; the astronomers being present in considerable force.

The dedication of the Peabody Academy of Science was an occasion worthy to occupy the attention of the Association at its opening session. A few notes on this Academy will be welcome to many readers. The Institution 
was founded at Salem in the year I867, by the munificence of George Peabody, with the design of promoting the study of science in his native county of Essex. The first Annual Report of the Trustees of this Academy, made in January, 1869, shows that it is already fully organized, with an able corps of officers and a well-ordered museum, library, \&c., and the activity of its Director and Curators is evident not only in the extent and fine condition of the collections, but in the zeal and ability with which the various publications of the Academy are conducted. Advantage was taken of the present occasion to make the formal transfer of the building of the Museum to the Trustees, and its delivery and acceptance by the Director, Mr. F. W. Putnam. In an eloquent address the President of the Academy, Mr. William C. Endicott, gave the history of the Museum from its foundation, in I80I, as the East India Marine Hall, to its purchase and reorganization in its present form. The Essex Institute, which is well known by its Proceedings, Bulletin, and Historical Collections, is now incorporated with the Peabody Academy of Science.

The address of Dr. B. A. Gould, the retiring President of the Association, dealt with the Position of Men of Science in America.

Everything which a hearty good will and an intelligent appreciation of science could do was done to promote the happiness and forward the plans of the Association and its members, alike by the city authorities of Salem, the various scientific bodies, and private individuals. We confess we should have been glad to learn that our English scientific men had been represented at the meeting, as America was represented at Exeter by Professors Newton and Lynan.

The Association will meet next year at Troy, New York, under the presidency of Professor Chauvenet, of St. Louis University.

The following, which were among the papers read at the meeting, will give an idea, not only of the great scientific importance of the congress, but of the direction in which many of the most eminent scientific men in America are working at the present time:-

SeCtion A. Mathematics, Physics, and Chemistry.-On the Total Eclipse of Ang. I869; B. Pierce.-On Quintuple Algebra; B. Pierce.-Determination of the Mechanical Equivalent of Heat, by means of the modern ice and cooling machines; P. H. Van der Weyde. - The Spectral Bands considered as harmonics of one or more fundamental longer waves, lying beyond in the invisible caloric rays; P. H. Van der Weyde.-On the andible transmission of musical melodies by means of the Electric Telegraph ; P. H. Van der Weyde.-Electricity not a self-existent fluid, but a mode of motion of matter; P. H. Van der Weyde.Flame Temperatures, in their relations to compositions and Iuminosity; B. Silliman and $H$. Wurtz. - On the relation between the Intensity of Light produced by the Combustion of Illuminating Gas and the Volume of Gas consumed; B. Silliman. -Causes of the Failure of Lightning Rods ; J. Bushee.-Conditions of a perfect Lightning Rod; J. Bushee.-The Laws of the Deflection of Beams tested by experiment; W. A. Norton.The physical theory of the Principle of the Lever; W. A. Norton. - Planetary Influence on Rainfall and Temperature; P. E. Chase. - The use of the Thermometer to determine the period of Solar Rotation; P. E. Chase--Some observations on the Solar Eclipse at Montreal, by Dr. C. Smallwood, with Photographs taken by Wm. Notman. Communicated by B. Edwards.-A new method of observing Contacts at a Solar Eclipse by the Spectroscope ; C. A. Young. - The Spectrum of the Solar Prominences and Corona, as observed at Burlington, Iowa, in the last Solar Eclipse, and the coincidence between the bright lines of Corona Spectrum and those of the Spectrum of the Aurora Borealis ; C. A. Young.-The Solar Eclipse, and the Outlines of the Corona as observed at Des Moins; T. Bassnett. - Remarkable case of freezing Fresh-water Pipes in Salt-water; W. W. Wheilden. --The Thermodynamics of Waterfalls; A. M. Mayer.-On some further evidence of the existence of a System of Arctic Winds; J. H. Coffin. - The present condition of Lighthouse Illumination in the United States; J. Henry. - A new method of rendering the Needle of a Galvanometer definitely astatic; M. G, Farmer.-On an improved construction of the Holtz Electrical Machine, adajted for the analysis of the phenomena of this variety of machine, and for Class-room use; R. E. Rogers.

SeCtion B. Gcology and Natural History.-Comparison of the Coral Fauma of the Atlantic and Pacific Coasts of the Isthmus of Darien, as bearing on the supposed former connection between the two Oceans; A. E. Verrill.-On certain Peculiarities in the distribution of Marine Life on the Sea-bottom of the Bay of Fundy ; A. E. Verrill.-American Phyllopod Crus. tacea; A. E. Verrill. - The Homologies and general structural relations of the Polyzoa; A. Hyatt.-Observations on a new genus of Polyzoa; A. Hyatt.-New Species of Fishes obtained by Prof. Orton in the valleys of the Maranon and Napo; T. Gill. - Notice of some new Fossil Plants, from Gaspé, discovered by Prof. J. W. Dawson; J. S. Newberry. -On some points in the Geology of North Carolina; W. C. Kerr.-Preliminary notice of the Lamellibranchiates of the Upper Helderberg, Hamilton and Chemung Groups: J. Hall. - On the Classification of the Diurnal Lepidoptera; S. H. Scudder.-The Morphology of the Abdominal Appendages of Butterflies; $S$. H. Scudder, - The value of the characters drawn from the external Armature of Lepidopterous Larvæ; S. H. Scudder. A classification of the Eggs of Butterfies; S. H. Scudder. - Two new genera of Extinct Cetacea; E. D.' Cope.-Discovery of the Ammonoosuc Gold Field; H. Wurtz. - Note upon the Palæotrochis; $\mathrm{H}$. Wurtz. - Notices of some new Tertiary and Cretaceous Fishes; O. C. Marsh.-Metamorphosis of Siredon into Amblystoma ; O. C. Marsh.-On some new Mosasauroid Reptiles from the Greensand of New Jersey ; O. C. Marsh.-Homologies of the Palrechinida; Alex. E. R. Agassiz.-On Surface Changes in Maine indicating the length of time since the close of the Quarternary Period; N. T. True-Compression as an agent in Geological Metamorphism, with illustrations of distorted pebbles in conglomerates; G. L. Vose. - On the Plasticity of Pebbles and Rocks; W. P. Blake.-Flora and Famna of the Freshwater Tertiaries of Oregon and Idaho; J. S. Newberry.-On new species of Fishes obtained by Prof. Orton in the Valleys of the Maranon and Napo; T. Gill.

Sub-Section C. Archeology and Ethnology.-Conjectural explanation of Uses of the Embankments of the Moind Builders; L. H. Morgan. - Discovery of the Remains of the Horse among the Ancient Ruins of Central America; O. C. Marsh.-Exhibition of a few interesting Implements collected by $R$. W. Haskins from Indian Graves on the banks of the Ohio, with special reference to the boring of holes in stone implements; F. W. Putnam.

\section{NEW STAR-ATLAS}

Mr. R. A. Proctor has planned a star-atlas on a plan which presents several advantages. The celestial sphere is to be divided according to this plan into twelve equal parts, each pentagonal in shape; but, each map being made circular, there is a slight overlapping, which prevents any star-group from being broken off at the edge of a map, as in all the arrangements hitherto adopted. Owing to the equality of the maps and the choice of a central projection (the equidistant) the distortion is reduced to a minimum. In fact, for the first time in the history of star-mapping, a plan is adopted by which, with a moderate number of maps, there is no appreciable distortion or scale-variation. The woodcut which gives (on a reduced scale and with inverted colours) a portion of Map 2 of the series (where it overlaps Map 4), exhibits some of the principal peculiarities of the new scheme. It will be noticed that though this portion belongs to the outer portion of the map (where the distortion is greatest) the figures between the parallels and meridians are of their proper shape. The arrow indicating precession in direction and magnitude (for 100 years) is a novel and very simple mode of exhibiting this important relation. The way in which the constellation-names are introduced is also new, and seems preferable to the old arrangement, in which the name straggling over the whole constellation at once confused the star-grouping, and was itself almost illegible unless printed in very large letters. The figure also includes instances of the mode of 